\title{
Gene therapy deserves a fresh chance
}

\author{
Initial interest in gene therapy waned after the technology failed to live up to expectation. Progress made \\ since has received little attention, but suggests that the pervading sense of disillusionment is misplaced.
}

n n the early 1990s, when the first human trials got under way, it seemed to many that the era of gene therapy was at hand: the techniques of modern molecular biotechnology would make it possible to repair genetic defects by inserting healthy DNA directly into a patient's cells. The excitement was short-lived. Lasting effects proved difficult to obtain in early trials, and the community quickly grew sceptical. Then, in 2003, when it was announced that several gene-therapy patients in a Paris-based clinical trial had developed leukaemia, and that one of them had died, the mood became bleak. Subsequent reports of successful and effective gene-therapy trials have done little to lift the prevailing sense of doom. For most researchers, gene therapy now seems like a dead end.

But it doesn't have to be a dead end - not if scientists shift their perspective on the risks of gene therapy to be more in line with that of clinicians.

Scientists are trained to focus on understanding the systems that they study in great detail. And when they devise therapeutic interventions - for example, harnessing a viral shell to insert a therapeutic gene into a patient's DNA - they naturally want those systems to be engineered with equally great care, and for them to be as near to risk-free perfection as possible.

Clinicians, by contrast, care for real patients in real time, which makes treatment decisions a matter of pragmatism. How do the risks stack up against the benefits for each available alternative - given that the risks are never zero? Clinicians are certainly not cavalier about their patients' well-being, but they may well end up prescribing a therapy that has a poorly understood mechanism and potentially large side effects because it gives the patient the best odds of recovery or survival. If they - and patients - had shied away from such dangers in the past, life-saving interventions such as organ grafts and bone-marrow transplants might never have been developed.

\section{Darwin and culture}

\section{A new series of essays traces the astounding variety of reactions to the theory of evolution.}

\footnotetext{
T he public reception of scientific ideas depends largely on two factors: people's ability to grasp factual information and the cultural lens through which that information is filtered. The former is what scientists tend to focus on when they give popular accounts of issues such as climate change. The assumption is that if they explain things very, very clearly, everyone will understand. Unfortunately, this is an uphill battle. The general public's average capacity to weigh facts and numbers is notoriously poor - although
}

From that perspective, the fact that, collectively, the Paris trial and others carried out since have produced positive results in some 20 patients out of a total of two dozen looms at least as large as the handful of leukaemia cases. To clinicians, such results suggest a treatment that is risky, but potentially life-saving - a new option for people for whom there are no alternatives.

However, this was not the view that prevailed. When the viral delivery vehicle itself turned out to be responsible for the leukaemia cases in the Paris trial, scientists deemed the trial a failure. Bad press ensued, proposals for gene-therapy clinical trials came under increased regulatory
"The results suggest a treatment that is risky, but potentially life-saving," scrutiny and standards for demonstrating safety were set higher than for other approaches. Unsurprisingly in such a climate, the biotechnology and pharmaceutical industries gradually dropped out of the gene-therapy pursuit. This corporate disinterest slowed clinical progress: academic centres are ill-equipped to make genetherapy vectors of clinical grade and scale, and research funding is typically insufficient to support clinical trials. More insidiously, it has become harder to recruit young talent to a field that is perceived as falling short of its promises.

To reverse this trend, it is time for researchers and industry to refresh their perspective on gene therapy and to consider its successes with as much intensity as its setbacks. The focus on adverse events has had positive consequences: researchers dissected the exact molecular mechanisms that led to cancer, designed better vectors, devised animal models to test these vectors and developed sophisticated assays for monitoring patients. As a result, both scientists and clinicians now have a battery of extraordinarily refined tools for preclinical and clinical studies of gene therapy. The field is ripe for further successes.

there is encouraging evidence that probabilistic reasoning can be improved by targeted education early in life (see page 1189).

Even more crucial, however, are the effects of the cultural lens. Over the coming month, Nature's Opinion pages will explore particularly vivid examples of these effects in the world's widely divergent reactions to Charles Darwin's ideas about evolution in the late nineteenth and early twentieth centuries (see page 1200).

In England, for example, the Church reacted badly to Darwin's theory, going so far as to say that to believe it was to imperil your soul. But the notion that Darwin's ideas 'killed' God and were a threat to religion was by no means the universal response in the nineteenth century.

Darwin's theory reached the world at a time when many people were looking for explanations for social, political and racial inequalities, 